\title{
The Economic Causes for the Scottish Union
}

DRING the seventeenth century the development of industry 1 and commerce gradually became the predominant interest of the three great nations of western Europe. In Holland this was especially so after the end of her war of independence; in England, after the civil war; and in France, during the administration of Colbert. The policy adopted by all was strictly protective. Its leading features were the encouragement of industry by prohibiting the import of foreign manufactures and keeping up the supply of raw materials, and the development of trade by encouraging the use of native shipping and forbidding or penalising the employment of foreign vessels. During the earlier part of the century the English looked upon the Dutch as their most powerful rivals. James I and Charles I both issued proclamations restricting the use of foreign vessels, but their regulations were neither so strict in themselves nor were they so severely enforced as were the more famous Navigation Acts of 1651,1660 , and 1663 , which were directed primarily against the Dutch. France also was preparing to enter the arena of commercial contest, and was developing her protective system. In 1659, partly in retaliation for the English act, a tax was imposed on all foreign ressels trading with France; and in 1664 and 1667 successive tariffs imposed heavy and almost prohibitive duties on the import of English and Dutch manufactures. English merchants were seriously alarmed. The whigs took up their cause, and in 1678, and again after the Revolution, trade with France was prohibited. It might have been said of England as the Dutch ambassador said of France, 'On remue ciel et terre ici pour óter aux étrangers la navigation et le cummerce.'

The position of Scotland at this time was one of great difficulty. At the time of her union with England in 1603 she was a country of undeveloped economic resources, almost medievall in her organisation of trade and industry. For the first half of the century she was preoccupied with religious interests, with her effort to resist the imposition of the English ecclesiastical system by - James I and Charles I. 'This struggle was continued, though with 
less vigour after the Restoration. At the same time industry was encouraged, and several manufacturing undertakings were started. It was not, however, until after the Revolution, when the religious controversy was settled, that the nation began really to devote herself to the pursuit of material interests. Then she found herself almost a century behind her neighbours in economic development. As Fletcher of Saltoun wrote in 1698, 'this Nation of all those who possess good Ports and lie conveniently for trade and fishing, has been the only part of Europe which did not apply itself to Commerce.'

Scotland had now to begin her struggle to make a place for herself amongst the commercial powers of Europe. In one way the time was favourable for such an attempt, for the Scottish parliament after the Revolution was more independent than it had been since the Restoration. Charles II and James II by their influence in the privy council and in parliament, through the lords of the articles, had been practically autocrats in Scotland. Bat at the Revolution the committee of the lords of the articles was abolished, and almost for the first time in its history the Scots parliament had the privilege of freedom of debate, and was in large measure exempt from royal influence. Nor was the authority either of William or of Anne as paramount in the privy council as had been that of Charles $\Pi$ and James $\Pi$. At a time, therefore, when Scotland was bent upon developing her economic resources, she was less dependent upon England and the English sovereign in internal affairs than she had ever been since James VI became king of England. But in all matters of foreign policy Scotland still counted for nothing. Her experience from 1660 to 1689 showed, what the events of 1689 to 1707 made still more clear, that she was to be neither represented nor considered, but to be treated as an alien nation, whenever her interests clashed with those of England. She might develop her industries, but she was not allowed to trade with the English plantations. Her sons might fight against France, but her interests were not considered when a treaty of peace was made. On the other hand, an independent Scots parliament might permit trade with France while England was at war with her, and introduce prohibited French goods into England through Scotland. Parliament might also give extensive privileges to a trading company whose settlements might endanger the king of England's foreign relations. The Scots could encourage illegal trade to the plantations, and might in time supply the Dutch with colonial produce to sell in Europe. On both sides the relation was felt to be unsatisfactory. Scotland wanted either to be independent as regards her foreign relations, which would involve entire separation from England, or to have her commercial interests made identical with those of England by commercial 
union. England wanted the two countries to be brought under one legislative authority. She could not allow a total breach of the union, as that would in all probability mean a renewal of the old alliance of France and Scotland. England was therefore forced to admit Scotland to trade privileges, in retarn for the establishment of one legislative authority and the assurance of the succession of the same sovereign for both countries. The union of 1707 gradually brought to an end that mutual antipathy between the two nations which had begun with the war of independence and was but little lessened in degree by the century of rule by one sovereign from 1603 to 1707.

A few years after James VI's accession to the English throne freedom of trade between the two countries, with the exception of native productions, wool, skins, hides, etc., was established by proclamation. This state of affairs continued until the invasion and conquest of Scotland by Cromwell. A complete union was then established in 1654. Not only was free trade established, but restrictions and regulations of trade and customs and excise daties were made the same for both countries. With the Restoration a great change came about. Scotland dialiked the union under Cromwell heartily. Her national pride was wounded by the English conquest and by the English garrisons and officials established in the country. The commercial incorporation had also been unpopular. As the industries of Scotland were undeveloped and her exports were chiefly raw materials? restrictions on the export of wool, hides, skins, etc., which were in force for English products, were injurious to her trade. Nor was England in love with the union. She had been obliged to contribute largely every year to the expenses of governing Scotland, and had not forgotten that the Scots had imposed presbyterianism upon her. Hence in 1660, with matual relief, the kingdoms returned to their former state, with separate parliamentary, ecclesiastical, and commercial systems, united only by a common bead.

The Scots took it for granted that they would continue to enjoy the freedom of trade with England and equality of trading rights with English ships which they had had during the reigns of James I and Charles I. The English parliament, however, decided otherwise, and Scotland was forced into the position of an alien nation. Her connexion with England became rather a burden than an advantage to her. Relations with continental countries were arranged in the interests of the more powerful country. Scotland had to contribute men and money for English wars, even when her commercial intercourse with her ancient friends the French and the Dutch, with whom she chiefly traded, was interrupted. She had no dealings with Africa and the East Indies, and but little as yet with Americs and the West. Wars with neighbouring nations therefore 
caused a great deal more suffering to Scotland than to England, for a great part of her trade was entirely stopped. The Scots were allowed no share in the English plantation trade. English states. men treated Scotland as a dependency, as they treated Ireland and the colonies, regulating their economic affairs entirely in the interest of England. Trade between Scotland and the plantations would not have been an advantage, and might have been a hindrance, to English trade, for with her low rate of import duties Scotland might become a depot for colonial produce. The English also feared that a prosperous Scotland might enable the king to be independent of his parliament in England. The acts dealing with Scottish trade to the plantations were the Navigation Acts of 1660 and 1663. The former debarred Scottish ships from transporting commodities from the plantations, and from bringing any goods except those of their own production into Englend, and also excluded them from the English coasting trade.' The latter enacted that no goods should be taken to the plantations except from England and in English ships. Scottish servants and victual might be taken from Scotland, but only in English ships. ${ }^{8}$ In 1695 these acts were made more stringent, and the penalties for disregarding them more severe. ${ }^{3}$ Restrictions were also placed upon the importation of certain Scottish goods into England. Heavy duties were imposed on salt, coal, cattle, and beer, and all goods brought into or carried from Scotland had to be taken by Berwick or Carlisle. ${ }^{4}$ The exportation of wool into Scotland was forbidden, and successive acts endeavoured to enforce the prohibition more strictly and made the penalties for its infringement more severe. ${ }^{5}$ In 1697 new and heavier duties were laid on Scottish linens. ${ }^{7}$ The Scottish parliament was not long in retaliating for these acts,

to the intent that the parliament of England being sensibill of thair 9. win prejudice may be moved to mak the tread betwixt the nations free ag' in the tyme of King James the Sixt. ${ }^{8}$

The 'Act for Encouraging of Shiping and Navigation' forbade any commodities to be brought into Scotland except in Scottish ships or ships belonging to the country of production. ${ }^{\circ}$ In 1663 the 'Act for ane new imposition upon English Commodities' placed heavy duties on English cloth and other woollen manufactures, and also a duty of eighty per cent. on all goods imported from England and on all English goods whithersoever they were imported. ${ }^{10}$

112 Car. II, 0. 18.

15 Car. II, c. 7.

27 and $8 \mathrm{Gal}$. III, c. 22.

+12 Car. II, c. 4 ; 14 Car. II, c. 18 ; 18 Car. II, c. 5.

- 14 Car. II, c. 11 - 14 Car. II, c. 7, c. 18 ; 7 and 8 Gal. II, c. 28.

9 Gul. III, c. 45.

- Records of Convention of Royal Burghs of Scotland, iii, 564.

- Acks of Parliament of Scotland, vii. 257.

10 Toid. vii. 465. 
There were therefore many restrictions on trade between the two countries. Remonstrances and complaints against the new regulations were many, especially in Scotland. The Scottish privy council wrote to the king in 1665 that

There hes bein so many addressea made to us for representing the sufferings of this Kingdome by the want of trade occasioned by ye late act of your parliament of England imposing so great customs upon our native commodities that our whole trade with that Kingdome is totally destroyed and by the act for navigation which is mad use of against the masters of our shipes as if they were strangers and not your Majesties subjects. That wee found it our deuty humbly to intreat your Majesty to interpose your authority for taking off these acts. ${ }^{11}$

Some of the English merchants trading to Scotland also com. plained that

the Trade and Commerce between your Majesties subjects of both kingdomes . . . is of late . . . wholly interdioted . . by which meanes the petitioners are reduced to grest Streights. ${ }^{12}$

The planters in Barbadoes petitioned for free trade with Scotland. They had found Scottish servants very useful, and now the English act forbade their transport in Scottish ships, and the Scottish act in Englisb ships.

Negotiations for a commercial union were begun in 1668, and for a complete union in 1670. England's refusal to open the plantation trade led to the failure of the former, and there was no real anxiety in either kingdom for the success of the latter. Lauderdale wrote from Scotland :-

You cannot imagine what aversion is generally in this Kingdome to the Union. The endeavour to have made us alaves by garrisons and the ruine of our trade by severe laws in England frights all ranks of men from having to doe with England. ${ }^{3}$

Like her greater neighbours Scotland entered into a protective policy. The want of imports from England and her own growing desire for commercial position caused an increase of industrial efforts, carried on more now by companies than by individuals. Acts encouraging manufactures were passed in 1661 and $1681 .{ }^{14}$ They forbade the import of manufactured goods and encouraged the import of raw materials, exempted the capital employed from taxation and the workers from military service, and bestowed other privileges. Under the system thus developed many manufacturing companies were founded, new manufactures were introduced, and the old-established industries developed and encouraged. Works

11 Privy Council Register, 5 May 1665.

12 Stato Papers, Dom., East India Entry Book i. 79.

1 Laviderdate Papors, ii. 154.

14 Acts of Parliament of Scotland, vii. 261 viii. 348. 
for making cloth, linen, sugar, silk, stockings, glass, paper, soap, cordage, \&c. sprang up, especially during the years from 1693 to 1695. A certain amount of the necessary capital came from England. These growing industrial concerns found that they could more than supply the home demand, and were therefore anxious to seek for foreign markets. In the English market there was a heavy daty on linen, one of the chief Scottish productions, and the newly established manufactures could hardly hope to compete with English home manufactures. Of the Scottish imports to England linen was, in spite of the duty, the most considerable. For the ten years before the union the average value of the linen imported yearly was nearly $40,000 l$., more than half the total value of the imports from Scotland. The other articles imported were chiefly coal, fish, cattle, and skins, and practically no manufactured goods except the linen. The principal exports from England were silk, both thrown and wrought, some woollen manufactures, some tobacco, sugar, and dyeing materials. Scottish exports to England generally exceeded English to Scotland by about 10,000 . a year. ${ }^{15}$

Besides this lawful trade a considerable traffic was carried on in wool. Large quantities were conveyed over the border into Scotland. Some of it was used in the growing cloth manufactories, where the finest cloths could not be made with native wool only. The rest, by far the greater part, was sent abroad to France and other countries on the continent. From the Restoration to the union the statute book contains many laws prohibiting the export of English wool to Bcotland. But in spite of these acts and in defiance of the officers placed upon the borders to enforce them the trade continued. In 1696 an act declared that

the several inhabitants of the several Counties and Shires of this Realm next adjoining to the Kingdom of Scotland and to the sea coasts do reap great profit and advantage by the Carrying ont of Wooll, Wooll-fells . . . [etc.] into the said Kingdom of Scotland, and exporting of them into France and other ports beyond the Seas. ${ }^{16}$

The trade increased in spite of all precautions. In 1705 the commissioners of the customs wrote to GodoJphin with regard to a petition from the clothiers and merchants of Leeds, Halifax, and the neighbourhood. They complained of

the Great Decay of their trade occasioned by rast quantityes of wooll which are dayly carried into Scotland from the Counties of Durham, Northumberland, and Cumberland, and from thence Transported into France and other Foreigne Parts. . The offenders have grown so Bold that they come above 50 miles and carry wooll off in Dispite of all Lawg. ${ }^{17}$

\footnotetext{
is For these facts see Customs Accounts, Pablic Record Office, Inspector-General's Ledger of Imports and Exports, 1697-1707.

107 and $8 \mathrm{Gul}$. III. c. 28 . "Treasury Out-letters; Customs, xiii, p. 390.

vOL. XXIV.-NO. XCIII. 
Jan.

Defoe says this trade reached such a height that the 'Famons Trade for wool to France by Rumney Marsh . . . was intirely Dropt, and France not supplyed only, but Glutted with Wool.'18 England's cloth manufacture was her most important industry. She therefore resented bitterly this supply of English wool to the manufactories of her rival France. It seemed impossible to take adequate precautions against the transport of wool over the borders. In Scotland the export was generally allowed, and when it was forbidden the customs authorities were not always able to enforce the prohibition. Goods were also smuggled across the border from Scotland into England, as French wines, which were prohibited altogether in England, tobacco, and other commodities which paid lower import duties in Scotland than in England. The restrictions on commerce and the evasions of these restrictions made the state of trade between the two countries very unsatisfactory, nor did they tend to promote friendly relations between them. But English and Scottish commercial interests clashed still more in the French, Dutch, and plantation trades.

Scottish trade both with the French and with the Dutch suffered severely during this period. Scotland and France had been old allies and friends, and the Scots hed enjoyed many commercisl privileges in France. Her adoption of the reformed religion and her union with England had dealt severe blows to the ancient alliance, but the Scottish merchants had succeeded in retaining their trading privileges during the first half of the seventeenth century. As the rivalry between England and France increased, and as Colbert's protective system became more stringent, the exemptions which the Scots had formerly enjoyed were gradually disregarded. The tax of 1659 on foreign shipping, though not at first imposed on Scottish vessels, was a great grievance, as was the inclusion of some Scottish imports in the new tariffs. Scotland blamed her union with England for her disabilities in France, but could not afford to retaliate, for she still disposed of a good deal of her produce in France, and the retarn cargoes of wine, salt, \&c. were very necessary. During the English and French wars the Scottish privy council and parliament occasionally prohibited trade with France, but nevertheless it was carried on very generally. English men-of-war and privateers were often sent to Scottish waters to endeavour to arrest the ships engaged in it. In 1691 the captain of the ship 'Pembroke,' sent by the lords of the admiralty for this purpose, wrote from Greonock :-

In my last I gave you an account that the Scots have a free trade with France, which I now confirm . . . they told me that free trading was allowed in these parts with France, and that their merchants must live. ${ }^{19}$

1. Defoe's History of the Union of England and Scotland, p. 65.

1- Home Office, Admiralty iv, 101. 
The Scots resented this interference very much. The merchants complained that

we are wholly frustrat of our trade to Portugal, Lighurn, or any other free port in the Streights, for the English do carry up all ships belonging to Scotland . . . suspecting that our ships are going to France. ${ }^{20}$

The English ships seized Scots vessels in their own waters and harbours which the Scots declared are ' ane Hayle Violatione of the Law of Nations.'

During William's first French war heavy duties were placed on fish, one of the principal Scottish exports to France. The Scots were much aggrieved that their interests were not considered at the negotiations for the treaty of Ryswick. Fletcher of Saltoun declared that they should have sent a minister of their own,

who might have obtained the re-establishment of the Nation in the Priviledges they had in France, which was totally neglected. And not withstanding the great and unproportionable numbers of Sea and Land Soldiers that we were obliged to furnish for the support of the War, yet not one tittle of advantage was procured to us by the Peace. ${ }^{21}$

A few years later the Scots parliament endeavoured to retaliate by forbidding the import of all 'Liquors of the growth of France.' ${ }^{29}$ This stroke of policy was not found successful, and in 1703 the importation of "Wines and other Foreign Liquors' ${ }^{23}$ was again allowed. The ministry urged that the customs on French wines were the chief fund for the civil list ; and on behalf of the trading interests it was alleged that ' unless this Act was past, the subjects may plow up their Towns and burn their Ships.' ${ }^{24}$ This act caused much indignant comment in England. 'The Scots Wine Act makes a great noise in this place. I have heard some members of Parliament declare they look upon it as the opening a back door to the enemies of England.' ${ }^{35}$ Burnet's account of the matter is as follows :-

Another act of a strange nature passed, allowing the importation of French goods: those who desired to drink good wine and all who were concerned in trede ran into it . . The Jacobites also went into it since it opened a free correspondence with France, and was certainly against the public interest of the government. ${ }^{26}$

Thus Scotland's trade with France was restricted and hampered because she was under the same king as England. And, as far as England was concerned, Scotland was the back door for the entry

2o Parliamontary Papers, xxi. 190.

31 Fletcher, Second Discourse, p. 16.

12 Acts of Parliament of Scotland, x. 278.

2 Ibid., xi, 112.

21 The Proceedings of the Parliament of Scotland begun at Edinburgh, 6th May 1708. (Advacates' Library, Edinburgh, Pamphlets, vol. 89.)

${ }^{25}$ Letter to Harley from London; Hist. MSS. Comm. Report, Portland Papors, iv. 70.

" Burnet, History of his Oton Times, v. 95. 
Jan.

of French goods. This state of affairs could not continue. Either England had to change her policy towards France, which she was not in the least likely to do as long as France supported the Stewarts, or Scotland would have to give up her French connexion, which again she was not likely to do without an equivalent.

The Dutch trade was also of great importance to the Scots merchants. The whole trading estate suffered very much during the ten years of Charles II's Dutch wars. T'he country was very poor, having not yet recovered from the effects of the civil wars, and poverty was increased by the restrictions on trade with England. Trade with Holland seems to have stopped altogether during the Dutch wars, and the condition of the country became still more deplorable. The revenue was reduced by a third, and discontent was so general that the government feared that if a landing should be effected by the Dutch, the people in the south and west would rise and join them. Nor did the Scots gain anything from the results of the wars; the consolidation of the colonies in America was, as yet, a matter of no concern to them. After the wars the commercial connexion was resumed again, and trade between Scotland and Holland again became considerable. The English always feared that, if the Scots should obtain any considerable share of the plantation or East India trades, the Dutch merchants would supply Europe with plantation prodace from Scotland. This was one of the reasons for the exclusion of the Scots from the colonial trade.

The demand of the French, Dutch, and other continentel markets was chiefly for raw materials. It was, however, necessary that the new manufactures which were springing up should find a demand which they could supply. The plantations, where the settlers had not yet begun to manufacture for themselves, were the ideal market, and from that the Scots were excluded by the Navigation Acts. Nevertheless the Scottish merchants succeeded in establishing a considerable trade with America, both in their own and in colonial ships, which brought plantation produce to Scotland and returned with a cargo of Scots manufactures in defiance of the Navigation Acts. The colonial records for the period contain very many complaints of illegal trade, generally with Scotland, Ireland, or Holland. The Scots exported their own manufactures, linen, coarse cloth, stockings, hats, etc. The privileges given to manufactories included the exportation of goods daty free, and therefore they were able to sell their cargoes chesply. The collector of duties in Carolina wrote in 1687 that the Scots ' are evidently able to undersell the English their goods . . . being cheap so that an Englishman must go away unfreighted or sell to vast disadvantage.' ${ }^{27}$ The plentation goods imported by Scotland $=$ S.P., Colonial, Colonial Entry Book, 100, p. 1. 
were chiefly tobacco and sugar. The duty on tobacco brought straight to Scotland was at the most threepence a pound, whereas if it was entered first in England the importer paid sixpence when it was afterwards brought into Scotland. The Scots merchants also took out servants, a very profitable commodity; 'sturdy and idle beggars, vagabonds and other profligat persons,' and 'obstinat phanaticks.' After they had served their time these immigrants often settled down and became prosperous planters and merchants. A number of settlers also went out, some of whom were scattered throughout the colonies, while in East New Jersey a number settled together. ${ }^{28}$ In 1703 Colonel Quary wrote to the lords commissioners of trade and the plantations :

The contest in East New Jersey is . . . Whether the Country shall ho a Scottish Settlement or an English Settlement. The Scotch have had for many years the advantage of the English by the Interest of a Scotch Governor. ${ }^{29}$

These colonists naturally wished to keep up their connexion with Scotland, and assisted their countrymen in carrying on their illegal trade. The merchants and shippers had various methods of avoiding the customs authorities. It was not difficult to land or to ship goods without the knowledge of the authorities when the coast line was as long as that of the American colonies. The traders also called at English ports, especially Berwick, took on board a few goods there, got a certificate, and then completed their cargo in Scotland. Another device was to forge certificates counterfeiting the seals of some English port. This was chiefly done in Glasgow, which, with the other Clyde ports, was the principal centre of the trade. Not only did the colonial governors and customs officials complain of this trade, but also English merchants, declaring that thair own trade would be ruined were it allowed to continue. Efforts to prevent it were made, and the English government even sent privateers and men-of-war to examine ships trading with Scotland. This was complained of by the Scottish privy council, not only as a drawback to their trade, but as an insult to the kingdom.

Our merchant ships have been seized and some of them carried away by English or Dutch privateers as if they were our Enemies. And furder we are informed that severall other merchant English shipps have taken out Commission of Mart from the Admiralty against unfree traders which we see they mostly make use of against our ships coming from the plantations and in our seas and rivers. Albeit be certaine that before this late warr none of our ships would be attacqued or molested on that account at sea But only in the ports and harbours of America.

to O. A. Hanna, Scotch Irish in America, vol. ii, ch. 2.

$\rightarrow$ Massachusetts Hist. Society Collections, 3rd Series, vols. vii and viii, 283. 
They therefore beg his majesty to give orders that no ships should be molested within Scottish harbours, in order to preserve 'the rights and honour of this your antient Kingdom which is undoubtedly absolute and independent.' so

Considered in relation to this trade, the act of 1695 , constituting the 'Company of Scotland trading to Africa and the Indies,' ${ }^{31}$ created some alarm. It was feared that, under its very comprehensive power, the Scots would gradually engross more and more of the American trade, in which they already had a large though illicit share. The commissioners of the customs and other authorities seemed to fear that the Scots would plant a colony upon some part of Pennsylvania or of the cosst not exactly specified in the charters and grants of land. There they might establish a depot for colonial produce, and as they could export their goods to Scotland duty free they might in time engross all the plantation trade and become the staple for Europe. Even when the settlement was finally attempted as far south as Darien there was still some alarm on this score. In 1699 Governor Bane, of New Jersey, wrote :-

The Bcotch Gentlemen amongst us are growne to a very great hight from ... the success that their Countrymen meet withall in their settlement of Caledonia. I cannot see but that the English interest and trade must of necessity fall if some spedy course be not taken for the stopeinge of their Groath . . . in time the evill may be too universall to be easily remedied, the trade of Fngland to these Colonies wholy discouraged and that of the Scotch nation advanced. ${ }^{32}$

The English act of 1696 ' for preventing Frauds and regulating Abuses in the Plantation 'Trade' took some precaution against the possible Scottish colony. It declared that no owners of property in America or the islands were to sell any land but to 'natural-born subjects of England, Ireland, Wales, or Berwick-upon-Tweed' sз without his majesty's licence. The Scottish trade with America was also dealt with in other clauses of the act, which made the provisions of former Navigation Acts more strict. In order to reduce the influence of the Scots settlers there it was enacted that places of trust in courts of law or in the treasury could only be held by natives of England, Ireland, or the plantations. In spite of the increased stringency of the trade regulations and the fact that a great deal of Scottish capital was locked up in the Darien Company, the trade with the plantations still continued. The Scots required a market for their manufactares, especially as their European trade was hampered by the French wars. In the plantations they found a ready sale for their principal wares, coarse

* Privy Council Register, June 29, 1694.

11 Acts of Parliament of Scotland, x. 377.

2 New Jersey Colonial Documents, ii. 288.

$7 \& 8$ Gol. iii, c. 22. 
cloth, linen, and stockings, which were more suitable for wear in the backwoods than at the courts of Versailles or St. James'. From this trade in particular the English were anxious to exclude the Scots. But it must have become more and more obvious that to concede entire freedom of trade and to gain entire control of it by establishing one legislative authority for the two kingdoms, would in the long run be a better policy than attempting to oust the Scots from the trade which they already had and were determined to keep.

Amongst the circumstances which made for anion the episode of the Scottish East India Company was of much importance. It brought into prominence the possible danger to English commercial interests from the existence of an independent parliament in Scotland. The English East India Company had been for some years engaged in a struggle with interlopers. After the Revolution the interlopers formed themselves into an association for the purpose of agitating against the existing company, but neither they nor the government of the company could succeed in obtaining what both alike desired, parliamentary powers. About this time an act was passed in Scotlend promising extensive privileges by parliamentary grant to companies formed in Scotland for engaging in foreign trade. A much-travelled Scot, William Paterson, with some English merchants desirous of taking part in the East India trade, formed a plan for getting, under this act, privileges for a Scottish company which, with the help of English capital and management, should establish a trade to India. Paterson no doubt had in his mind a cherished project of his own for establishing a depot on the Isthmus of Panama for both East and West Indian goods. But as long as English merchants had the principal voice in the management of affairs this scheme was not brought forward. In 1695 the Scottish parliament passed an act incorporating twenty-one persons in the 'Company of Scotland trading to Africa and the Indies.' They were given very extensive privileges, exemption from taxation for twenty-one years, powers of treating with foreign nations, raising troops, making settlements, \&c., and were also assured the support of royal authority in insisting on reparation for any damage done to the company and its possessions. In passing this act the commissioner, Tweeddale, doubtless exceeded his instructions from the king. Those concerned in the company seemed to expect opposition, and accordingly hastened to raise subscriptions before the English parliament met. All the business was carried on in London, and between August and November 300,000l. (the amount fixed for English shareholders) was subscribed, and 75,000l. of it paid up. But as soon as parliament met in November, their attention was directed to the company. Representatives of the 
East Indian and African trades and customs commissioners were examined, the directors of the company were summoned before the house of commons, and a resolution to impeach them was passed. An address was presented to the king representing the extent of the privileges granted to the company and the possible danger to English trade :-

A great part of the Stock and Shipping of this Nation will be carried thither [to Scotland] and by this means Scotland be made a Free Port for all East India Commodities; and consequently these several places in Europe which were supplied from England will be furnished from thence. ${ }^{34}$

The parliamentary investigations proved the ruin of the company, for nearly all the capital subscribed was withdrawn and the management of basiness was left to the Scots directors. Scottish patriotism was aroused by English opposition, and the affair became one of national importance.

'Twas the notice the parliament of England first took of it made the whole nation throng in to have some share, and I'm of opinion the resentments people are acted by, are the greatest supplys that furnishes life to that affair. ${ }^{3 s}$

Under Scottish control Paterson's scheme was adopted, an expedition sent out to the Panama Isthmus, and the ill-fated settlement begun at Darien. The failure of the scheme showed the English that the Scots could conceive and could obtain parliamentary authority for enterprises which might make them successful rivals of the great English companies. It also showed the Scots, though their disappointment and dislike of England were too keen to allow them to realise it, that they would find it hard to succeed in large commercial enterprises without English help and support. William III saw that the present state of relations between the two countries could not continue. It was impossible that the Scottish parliament should authorise and give political powers to companies which might interfere with the king of England's political engagements or cause a rupture with his allies. In almost his last words he recommended the parliament of England to set on foot a treaty for union; his majesty being satisfied 'that nothing can contribute more to the present and futare Peace, Security, and. Happiness of England and Scotland than a firm and entire Union between them.'

When, after Anne's accession, commissioners for both countries were appointed to treat for a union, the English commissioners had agreed to open the plantation trade, but the Scots insisted on the continued existence of their African compans,

"Journals of the House of Lords, $\mathrm{x}, 611$.

3s Lord Justice Clerk (Adam Cockburn) to Lord Tallibardine, December 1697; Hist. NSS. Comm. Report xii, part viii, p. 53. 
and matters were at a deadlock on this point at the time when the negotiations were adjourned..$^{36}$ Numbers of pamphlets were published on the subject. Generally written from the Scottish point of view, some oppose, but the greater number advocate the union. They dwell on the necessity for some change in the present relations of the two countries for the development of Scottish industry and trade. England, France, and Holland are all competing for the trade of the world, and Scotland must also enter upon the contest: "The genius of this nation, all their thoughts and inclinations . . . seem to be turned upon Trade.' The writers generally point to the freedom of trade enjoyed with England until 1660, and the 'preclusions, restrictions and hardships which have been put upon us in matters of trade since the Restauration '; as well as to the necessity for colonial markets. The disadvantages which Scotland's connexion with England has brought her in her relations with France are often emphasised. On this account she has lost all her ancient privileges in that kingdom, and English wars interrupt her trade thither, and also to Holland. The failure of the Darien expedition is attributed to English jealousy. The English connexion has been a

loose and irregular tye . . . wherein we are not considered as subjects, nor allies, nor friends, nor enemies, but all of them, only when, where, how and how long our taskmesters pleases. ${ }^{37}$

All writers agree in declaring that the present state of affairs has become intolerable, and that Scotland must have either a complete union with England or a complete separation from her. The adoption of the latter course would probably mean alliance with France, and the danger which this would involve to England is pointed out.

Popular feeling against England ran very high when parliament met in 1708 . Several acts were passed calculated to precipitate either a breach or a union with England. These were the 'Act anent Peace and Warr,' 38 providing that after Anne's death no sovereign of Scotland and England could declare war without consent of the Scottish parliament, and that any such declaration made without parliamentary consent was not binding upon the people of Scotland; acts allowing the importation of wines ${ }^{39}$ and the exportation of wool, ${ }^{40}$ and the act for the security of the kingdom." This last declared that after Anne's death the sovereign was to be chosen by parliament, and was not to be the same as the successor to the English throne, unless during her majesty's reign the 'sovereignty of the Kingdom, the power of Parliament, and

3* Acts of Parliament of Scotland, xi, App., p. 160.

37 Proposals and Reasons for Constituting a Courcil of Trade. Edinburgh, 1701.

"Acts of Parliament of Scotland, xi. 107.

* Ibid., xi. 112.

to Ibid., xi. 190.

4. ?bid., xi. 136. 
Jan.

the religion, liberty, and trade of the nation' were secured from 'England or any foreign influence.' Very strong feeling was aroused in England by these acts. The dangers of the commerce and correspondence which could be kept up with France by means of the wine act and the act of peace and war were obvious to all. As Godolphin wrote to the Lord Chancellor of Scotland,

The Act for putting the power of Peace and War into the Parliament might prove extremely inconvenient both to England and Bcotland . . England is now at war with France: if Scotland were in peace and consequently at liberty to trade with France would not that immediately necessitate a war betwixt England and Scotland also ? 48

The state of affairs in Scotland was discussed at length in both houses of parliament. In the house of lords, Somers declared that

it was of the highest consequences to England to provide for their awn security against the danger they were in from such Acts, and to prevent the like in time to come..$^{3}$

Several speakers reminded the house of the unwise policy which had been pursued in England towards Scotland, especially in the Darien business. The report of the committee was that,

upon consideration of the several Acts of Parliament passed in Scotland and the dangerous consequences that may follow from thence as to the trade and as to the present and future peace of this Kingdom,

some new laws must be made to 'prevent these ill effects.' 14 Measures were discussed for prohibiting Scottish imports, declaring the Scots aliens in England and the plantations, taking more strict measures to prevent the smuggling of wool, placing armed forces on the borders, and stationing ships to hinder trade with France. The result was an 'Act for the effectual Securing the Kingdom of England from the apparent Dangers that may arise from several Acts lately passed in the Parliament of Scotland.' 15

This act provided that commissioners should be appointed to treat for a union. If the succession was not settled in Scotland as it was in England, natives of Scotland, except those settled in England or the dominions or serving in the army or navy, were to be declared aliens. Until the same condition was fulfilled no Scots cattle, linen, sheep, or coal were to be brought into England. This would be a great blow to Scottish trade. Cattle and linen were very important exports, and the Scots had too few markets open to them to be able to afford the loss of that of England. The English were beating them at their own tactics. The Scots had hoped by their four acts to wring concessions in trade from England.

1: Stair Anrals, i., App. p. 38.

4. Jerviswood Correspondence, p. 15. " Journals of Hotwe of Lords, xvii. 585 .

is 3 and 4 Ann. c. 6. 
Now England was threatening penalties on their trade if they did not adopt her succession policy or accept a union. Roxburghe wrote from London in 1704, after hearing debates in the Lords:-

It appears from what was said that no concessions are to be expected barely apon your coming into the Sucoession; and so treatys, in order to the Succession, signify nothing . . . in short you may settle the Succession upon limitations if you please, or you may accept of a Union. If you do neither you may expect of all the mischief that can be done you, for as it was said you and your independence are not so grest but that you must depend either on France or England, and sure they will not suffer you to depend on France if they can help it. ${ }^{46}$

In another letter he said: ' I am thoroughly convinced if we do not go into the Succession or an Union very soon Conquest will certainly be upon the first Peace.' 17

The Scottish parlisment met again in Jane 1705. The queen's message urged them to appoint commissioners to treat for a union, and after hot discussion the act for a treaty with England was passed. The reasons in favour of it would be, says one, "Trade with most, Hanover with some, eqse and security with others, together with and generall aversion at civill discords, intolerable poverty, and the constant oppression of a bad Ministry.' ${ }^{48}$ Soon after this the clauses in the English act dealing with prohibition of imports and making the Scots aliens were repealed. The meetings of the commissioners for union lasted from April till July 1706. The most important provisions of the treaty were those abolishing all restrictions on commercial intercourse between England and her dominions and Scotland and uniting the two parliaments. With regard to the African company, the English commissioners refused to allow it to continue in existence, but agreed that the shareholders should be compensated. The treaty was brought first before the Scottish parliament. It met with much opposition there and also throughout the country. It seems probable, however, that the numerous petitions sent in against it were largely the work of the Jacobite party. The adrocates of the union based their support on the ground of the solid advantage to Scotland in larger opportunities for economic development and increased security. The opposition as a rule was for patriotic reasons-the loss of independence and name by the ancient kingdom of Scotland. The dislike of England and the English was still very strong. The treaty was, however, ratified with but few alterations in January 1707, and these changes were conceded by the. English parliament, which passed the treaty in March with but little difficulty.

The Scots since the Revolution had set their minds upon obtaining for themselves a share in the world's trade. They found

to Jervistoood Correspondence, p. 28.

"Ibid., p: 28.

4s Ibid., p. 189. 
that this ras impossible without English help, and that they could not force free trade from England for any less return than their assent to an incorporating union. England at the same time was engaged in a great war with a great rival, involving commercial as well as political interests. It was necessary for her that Scotland should not be driven eitber for commercial or dynastic reasons into the arms of France. On the other hand, a leading object of her policy had been the maintenance of the Navigation Acts, and especially the exclusion of Holland. The Scottish trade with Holland threatened to let in the Dutch through Scotland. Another great object of English policy at the time was the monopoly of the plantation trade. Scotland had already got some share of this trade. It was better that she should be admitted to carry on the trade under English regulations than that she should continue outside them, become an intermediary for the Dutch, and enable them to retail colonial produce in Europe. The danger of actual commercial rivalry at the time was not great, but the whigs were carrying out a very consistent policy-the protection of English industry and the enlargement of English markets. An independent Scotland endangered the whole system. To remove these dangers and to obtain a united parliament and a common settlement of succession for the tro countries England was willing to share her cherished trade privileges with her northern neighbour.

Theodona Кеiтh. 